\title{
AIRS observations of seasonal variability in meridional temperature gradient over Indian region at $100 \mathrm{hPa}$
}

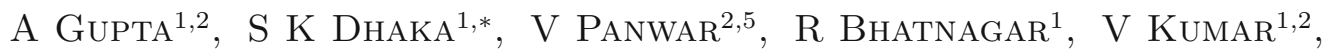 \\ SAVITA M DATTA ${ }^{3}$ and S K DASH ${ }^{4}$ \\ ${ }^{1}$ Department of Physics, Rajdhani College, University of Delhi, New Delhi 110 015, India. \\ ${ }^{2}$ Department of Physics and Astrophysics, University of Delhi, New Delhi 110 007, India. \\ ${ }^{3}$ Maitreyi College, University of Delhi, New Delhi 110 021, India. \\ ${ }^{4}$ Centre for Atmospheric Sciences, Indian Institute of Technology Delhi, New Delhi 110 061, India. \\ ${ }^{5}$ Research Institute for Sustainable Humanosphere, Kyoto University, Uji, Kyoto 611-0011, Japan. \\ ${ }^{*}$ Corresponding author.e-mail: skdhaka@yahoo.com; skdhaka@gmail.com
}

To investigate the temperature changes at $100 \mathrm{hPa}$ over Indian region from Arabian Sea (AS) to Bay of Bengal (BOB), analysis is performed using Atmospheric Infra Red Sounder (AIRS) temperature and outgoing long-wave radiation (OLR) data of 9 years (2003-2011). Fine-scale temperature variations have been studied and shown for summer (March-April-May, MAM), summer monsoon (June-JulyAugust-September, JJAS) and winter (November-December-January-February, NDJF) months. Similarities and differences in the latitudinal and longitudinal variation of temperature and the possible causes have been examined. During MAM and NDJF, the temperature increases latitudinally by $\sim 2-3 \mathrm{~K}$ and $\sim 4-5 \mathrm{~K}$ from $3.5^{\circ}$ to $20.5^{\circ} \mathrm{N}$, respectively. However, the temperature decreases by $\sim 2.0-2.5 \mathrm{~K}$ during JJAS. A similar contrasting behaviour is observed in latitudinal temperature gradient. For MAM and NDJF, the gradient decreases from $\sim 0.18$ to $\sim 0.14 \mathrm{~K} / \mathrm{deg}$ and $\sim 0.25$ to $\sim 0.18 \mathrm{~K} / \mathrm{deg}$, respectively, as we move longitudinally from $60^{\circ}$ to $90^{\circ} \mathrm{E}$; however, for JJAS, it increases from $\sim 0.10$ to $\sim 0.14 \mathrm{~K} / \mathrm{deg}$ over the same longitudes. It is found that latitudinal temperature gradient for NDJF is larger by about a factor of 1.5. Analysis suggests latitudinal change in temperature occurs due to low OLR (proxy of convection) and its northward progression during summer monsoon. Correlation coefficient $\left(R_{\mathrm{xy}}\right)$ between OLR and temperature is computed latitudinally $\left(3.5^{\circ}\right.$ to $\left.20.5^{\circ} \mathrm{N}\right)$ at different longitudes and during JJAS (monsoon months), $R_{\mathrm{xy}}$ is negative $(\sim-0.73)$ over $60^{\circ}$ and $70^{\circ} \mathrm{E}$ longitudes, but it turns positive $(\sim 0.92)$ over $80^{\circ}$ and $90^{\circ} \mathrm{E}$ longitudes (which is convectively active region), suggesting a close association between low temperature and low OLR. Land-sea contrast is also observed in temperature at $100 \mathrm{hPa}$ with a slight increase $(\sim 0.5 \mathrm{~K})$ from sea to land.

\section{Introduction}

Temperature in the upper troposphere and lower stratosphere in the Earth's atmosphere plays an important role in understanding radiation budget and various chemical species (Rosenlof et al. 2001; Pan et al. 2004). An important aspect of studying the troposphere and lower stratosphere

Keywords. Meridional temperature gradient; Atmospheric Infra Red Sounder (AIRS) data; Indian summer monsoon; outgoing long-wave radiation (OLR). 
temperatures and their trends is a better understanding of the exchange of the trace constituent between the troposphere and stratosphere transport across the tropopause. Indeed, the tropopause marks the transition between the troposphere and the stratosphere and it plays an important role in stratosphere-troposphere exchange and wave propagation between the two regions (Holton et al. 1995; Baray et al. 1998; Sorensen and Nielsen 2001). Newell and Gould (1981) examined the spatial distribution of tropopause temperature and concluded that during winter months (NovemberMarch), the tropospheric air could enter the lower stratosphere through the Indonesian region where the tropopause temperatures are the lowest and have also shown that the region of cold tropopause temperature expands towards the Bay of Bengal (BOB) and the Indian tropical region during premonsoon and monsoon months, suggesting that the Indian tropical region may be participating in the stratospheric dehydration. However, the dry air could have entered the stratosphere either by overshooting convective turrets making the tropopause region much colder than the surroundings (Sherwood and Dessler 2001). Highwood and Hoskins (1998) have shown, mainly on the basis of the European Centre for Medium-Range Weather Forecasts (ECMWF) analysis, that during summer (June-August) months, the tropopause can be high and cold in the Asian monsoon region. They have also mentioned that it is difficult to compare the ECMWF and radiosonde climatology because of missing data over the Asian region. Randel et al. (2000) presented global variability and trends in tropopause temperature on the basis of National Center for Environmental Prediction (NCEP) reanalysis and noted that in July, the tropical tropopause temperature minimum occurs over the Indian monsoon region centered near $20^{\circ} \mathrm{N}$. Ratnam et al. (2005) showed the distribution of the cold tropopause over $\sim 20^{\circ} \mathrm{N}$ and $0^{\circ}-120^{\circ} \mathrm{E}$ covering the Arabian Sea (AS) region, during northern summer (June-August), further analysis of its causes has not been reported so far. Jiang et al. (2004) have shown that most of the deep convection events occur in the western Pacific and Indian monsoon regions and discussed that low temperatures in the tropical tropopause are associated with the centre of deep convection. This again brings in the Indian-Asian summer monsoon region into focus.

It is apparent from the above discussion that the convection activity plays a significant role in cooling the tropical tropopause region. However, very limited observations exist over these regions during monsoon season. Bhat et al. (2002) analysed temperature data of active and weak phase of convection from observations taken onboard ocean research vessel (ORV) Sagar Kanya (SK) during the Bay of Bengal Monsoon Experiment (BOBMEX) campaign (20 July-29 August 1999) over the BOB and noted that temperature near the tropopause height during the active phase of convection is cooler by $2 \mathrm{~K}$ than that observed during the weak phase. This provided a direct evidence of the influence of convection activity on the temperature of the tropopause region.

Recently, Dhaka et al. (2010) have analysed the relation between convective available potential energy (CAPE) and temperature at $100 \mathrm{hPa}$ using data from different stations over the Indian region. They have suggested that the increase in convective activity is associated with decrease in temperature at $100 \mathrm{hPa}$ and also examined the presence of solar signal in temperature at the same pressure level. Association of outgoing long-wave radiation (OLR), taken as proxy of convection, and temperature has also been examined using limited data by Jain et al. (2010). They have examined the relative spatial distribution of OLR and temperature at $100 \mathrm{hPa}$ using daily mean OLR (obtained from NOAA) and daily mean temperature (taken from NCEP reanalysis) over a period of 24 June-15 August 2002 covering BOB $\left(10^{\circ}-20^{\circ} \mathrm{N}, 85^{\circ}-90^{\circ} \mathrm{E}\right)$ and Indian land-mass (ILM, $10^{\circ}-20^{\circ} \mathrm{N}, 72.5^{\circ}-82.25^{\circ} \mathrm{E}$ ). They observed that low temperature and low OLR occur over the same broad area, though all OLR and low temperature areas do not overlap.

All the above studies to analyse the variation in temperature at $100 \mathrm{hPa}$ or at tropopause level and its association with convection are done using radiosonde data or NCEP reanalysis data at few or at different locations. But, with the advent of technology and sensitive instruments like Atmospheric Infrared Sounder (AIRS) onboard the NASA's Earth Observing System satellite, we can observe the variation in temperature and its association with convection globally on a very fine spatial and temporal scale covering AS, Indian land region and $\mathrm{BOB}$ region which could not be done extensively in the past.

The main objective of the present study is twofold - first to examine the variation in temperature at $100 \mathrm{hPa}$ latitudinally and longitudinally at a very fine scale $\left(1^{\circ} \times 1^{\circ}\right)$ and secondly to examine the association of this variation in temperature with the phenomena of convection. The height level of $100 \mathrm{hPa}$ is selected as it denotes standard level near the tropopause (Randel et al. 2000).

To examine the seasonal latitudinal variations in temperature, we have analysed temperature data during March-April-May (MAM), JuneJuly-August-September (JJAS) and NovemberDecember-January-February (NDJF), which are the representation of summer, summer monsoon 
and winter seasons, respectively. We have used 9 years (2003-2011) of monthly averaged temperature data from AIRS at $100 \mathrm{hPa}$. The $100 \mathrm{hPa}$ level lies below the cold point tropopause level which is located mostly between 92 and $98 \mathrm{hPa}$, as noted from AIRS data for the region $3.5^{\circ}-20.5^{\circ} \mathrm{N}, 60^{\circ}-$ $90^{\circ} \mathrm{E}$. We have also analysed longitudinal variation in temperature to show the differences over land and sea, which could not be understood at a fine scale earlier in this region, due to paucity of data.

\section{Data}

We have used AIRS (AIRX3STM) version 5 level 3 research quality product (http://airs.jpl.nasa. gov/) for our analysis. Each product is separately derived from microwave (MW)-only retrievals and combined infrared/microwave (IR/MW) retrievals (using cloud clear algorithm method as described by Susskind et al. 2003). Monthly averaged temperature data at $100 \mathrm{hPa}$ over Indian region $\left(3.5^{\circ}-\right.$ $20.5^{\circ} \mathrm{N}, 60^{\circ}-90^{\circ} \mathrm{E}$ ) during MAM, JJAS and NDJF for 9 years (2003-2011) with a high spatial resolution $1^{\circ} \times 1^{\circ}$ have been used. The AIRS/Advanced Microwave Sounding Unit (AMSU) sounding system (Aumann et al. 2003; Chahine et al. 2006) on the NASA Aqua platform has been operational since 1 September 2002. The AIRS and AMSU instruments are each crosstrack scanning nadir sounders that are co-aligned and have a swathe roughly $1650-\mathrm{km}$ wide. The AIRS instrument is a 2378-channel grating spectrometer measuring infrared radiance at wavelengths in the range of 3.7-15.4 $\mu \mathrm{m}$ with a horizontal resolution of about $13.5 \mathrm{~km}$ at nadir (Aumann et al. 2003). The AMSU instrument is a 15-channel microwave radiometer with a horizontal resolution of about $45 \mathrm{~km}$ at nadir (Lambrigtsen 2003). Nine AIRS fields of view are contained within each AMSU field of view. The AIRS/AMSU geophysical retrieval method uses an iterative, least-square physical inversion of cloudcleared infrared radiances, obtained from a combination of infrared and microwave observations. The algorithm is referred to as the AIRS/AMSU combined retrieval and was described by Susskind et al. (2003, 2006). Following common practice, any discussion of AIRS in this work implicitly refers to the AIRS/AMSU system. The AIRS sounding system produces about 324,000 temperature profiles every day, separately by ascending and descending orbits. The AIRS Level-3 (L3) temperature profile product is the gridded averages of the AIRS L2 temperature profiles on horizontal $1^{\circ}$-latitude $\times$ $1^{\circ}$-longitude grids and 24 pressure levels from 1000 to $1 \mathrm{hPa}$. Validation of AIRS temperature retrievals with radiosonde over various regions of high latitudes had already been performed (special issue in JGR - Divakarla et al. 2006; Fetzer 2006; Gao et al. 2006; Yunck et al. 2009 (please see their figure 2)). It should also be noted that only high quality measurements from level 2 products are used to derive the level 3 products avoiding the fallback cases (Olsen et al. 2007a, 2007b). The number of temperature retrievals obtained per month at $100 \mathrm{hPa}$, were 23-26 for a particular latitude and longitude, which is a good representation of vertical temperature profiles. The number of retrievals was high as $100 \mathrm{hPa}$ lies above the top level of clouds (mostly located around 200-250 hPa), confirmed from the AIRS cloud pressure data. Tobin et al. (2006) showed that the mean AIRS bias between the surface and $100 \mathrm{hPa}$ ranged only between $\pm 1 \mathrm{~K}$ with the largest magnitudes occurring at $100 \mathrm{hPa}$. However, comparisons of AIRS and Constellation Observing System for Meteorology Ionosphere and Climate (COSMIC) soundings (boreal summer and fall) show that AIRS systematic error for $100 \mathrm{hPa}$ temperatures is closer to $\pm \sim 0.5 \mathrm{~K}$ (Liang et al. 2011). This indicates that the observed temperature signal has a high measurement accuracy at $100 \mathrm{hPa}$, which gives us confidence in the observed temperature features. To examine the association of low temperature with enhanced convection (i.e., low OLR values) 9 years of monthly average OLR data from AIRS is also used. Since OLR and temperature data are taken from the same satellite at a very fine temporal and spatial scale, the association between them could be observed very clearly. With the use of such high resolution satellite data, one can examine the gradual and systematic northward change in temperature at a fine scale.

For the present analysis, we have used the combined IR/MW retrievals temperature data, however AIRX3STM provides MW temperature data as well. To examine the difference between two kinds of retrievals (MW and IR/MW), we have also shown their corresponding bias with latitude for each season over the Indian region, using 9 years of temperature data (see figure A1). We noted that MW retrievals shows little larger (smaller) value of temperature $(\sim 0.5-1.0 \mathrm{~K})$ in comparison to combined retrievals (IR/MW) for latitude range $\sim 3.5^{\circ}-9.5^{\circ} \mathrm{N}\left(\sim 9.5^{\circ}-20.5^{\circ} \mathrm{N}\right)$.

\section{Results and discussion}

In this section, we present the results pertaining to latitude-longitude sector $3.5^{\circ}-20.5^{\circ} \mathrm{N} ; 60^{\circ}-$ $90^{\circ} \mathrm{E}$ over the years $2003-2011$ for summer (MAM), summer monsoon (JJAS), and winter (NDJF) 
months to analyse the similarities and differences in temperature variations in the upper troposphere at $100 \mathrm{hPa}$. Average features of latitudinal variation of temperature (i.e., meridional temperature gradient) during MAM, JJAS and NDJF are computed and shown. In addition, to examine the association between temperature variation and convection, we have also analysed 9 years of OLR data from AIRS. OLR data are taken as a proxy of convection. The longitudinal variations in temperature are also analysed at $60^{\circ}, 70^{\circ}, 80^{\circ}$ and $90^{\circ} \mathrm{E}$ to show the differences over land and sea.
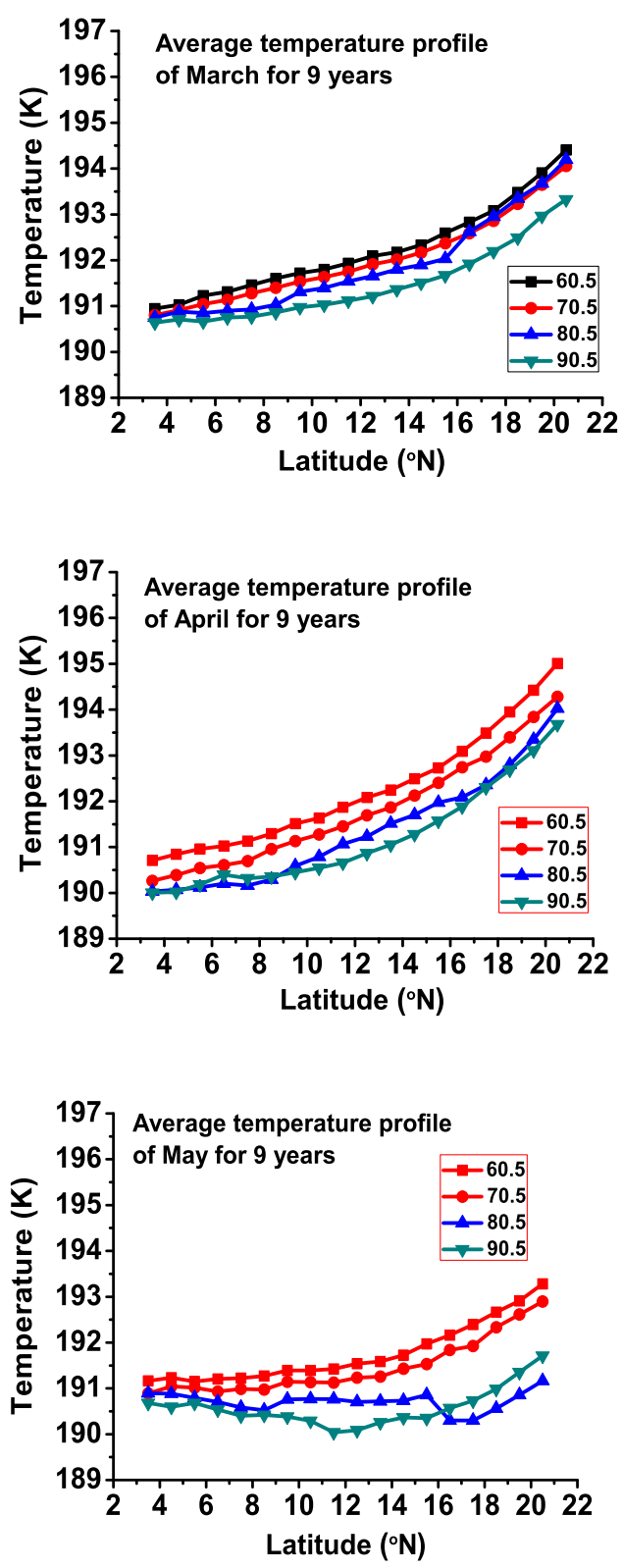

3.1 Latitudinal variation of average temperature and OLR during 2003-2011

Figures 1(a, b, c), 2(a, b, c, d) and $3(\mathrm{a}, \mathrm{b}, \mathrm{c}, \mathrm{d})$ show latitudinal variation of temperature and OLR at different longitudes for summer, summer monsoon, and winter months, respectively. Monthly averaged temperature data (spanning over 9 years) is plotted to show the average features of temperature variations during 2003-2011, which is a good approximate representation of climatology of thermal structure in the upper troposphere at $100 \mathrm{hPa}$.
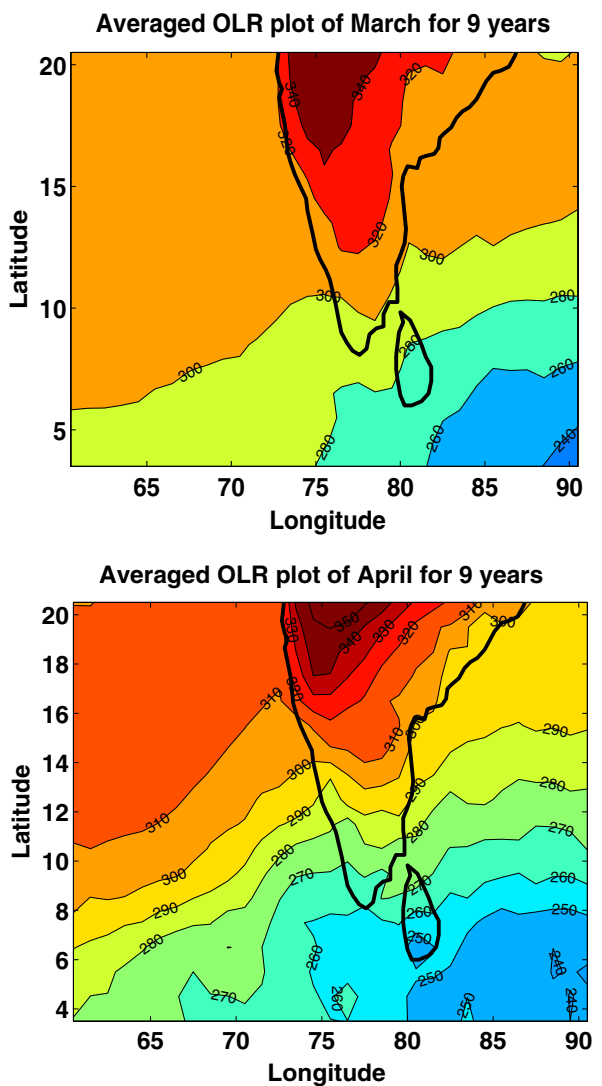

Averaged OLR plot of May for 9 years

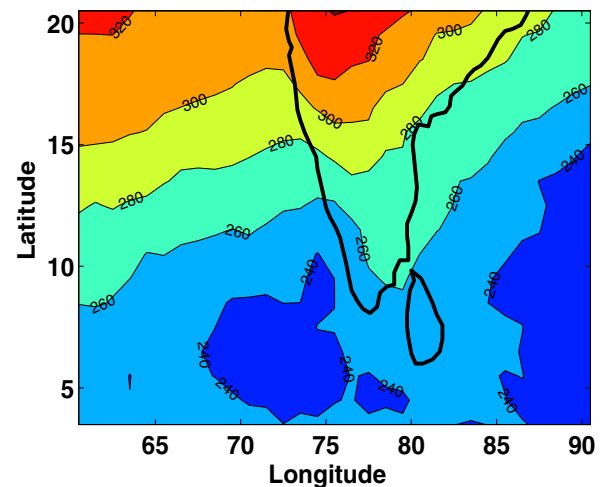

Figure 1. Left panel shows 9 years averaged (from 2003 to 2011) temperature for the summer months (March, April and May) and right panel shows 9 years averaged (from 2003 to 2011 ) OLR over the Indian region $\left(3.5^{\circ}-20.5^{\circ} \mathrm{N}, 60^{\circ}-90^{\circ} \mathrm{E}\right)$. Indian coastal line is shown. 

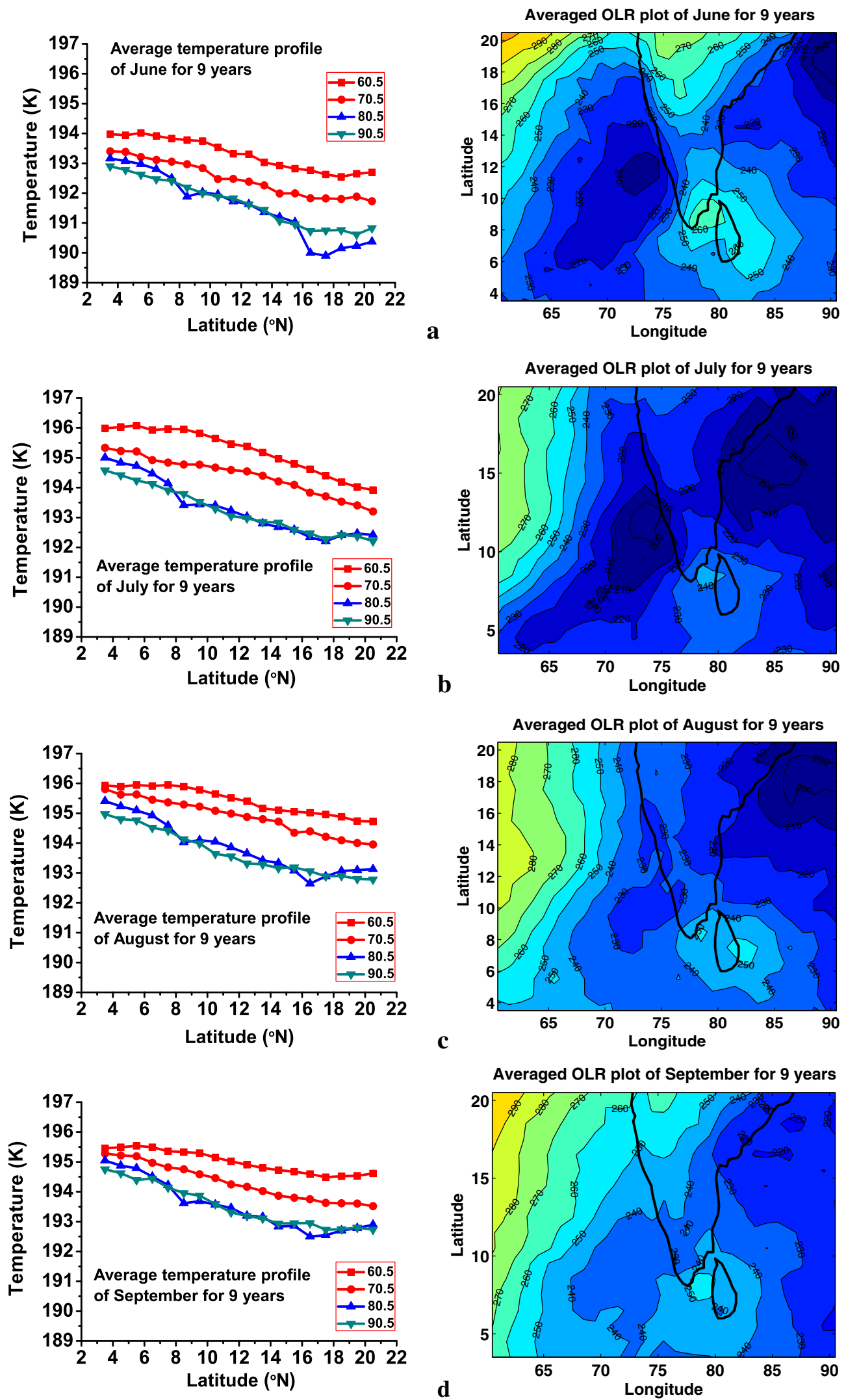

Figure 2. Left panel shows 9 years averaged (from 2003 to 2011) temperature for the summer monsoon months (June, July, August and September) and right panel shows 9 years averaged (from 2003 to 2011) OLR over the Indian region $\left(3.5^{\circ}-20.5^{\circ} \mathrm{N}, 60^{\circ}-90^{\circ} \mathrm{E}\right)$. 

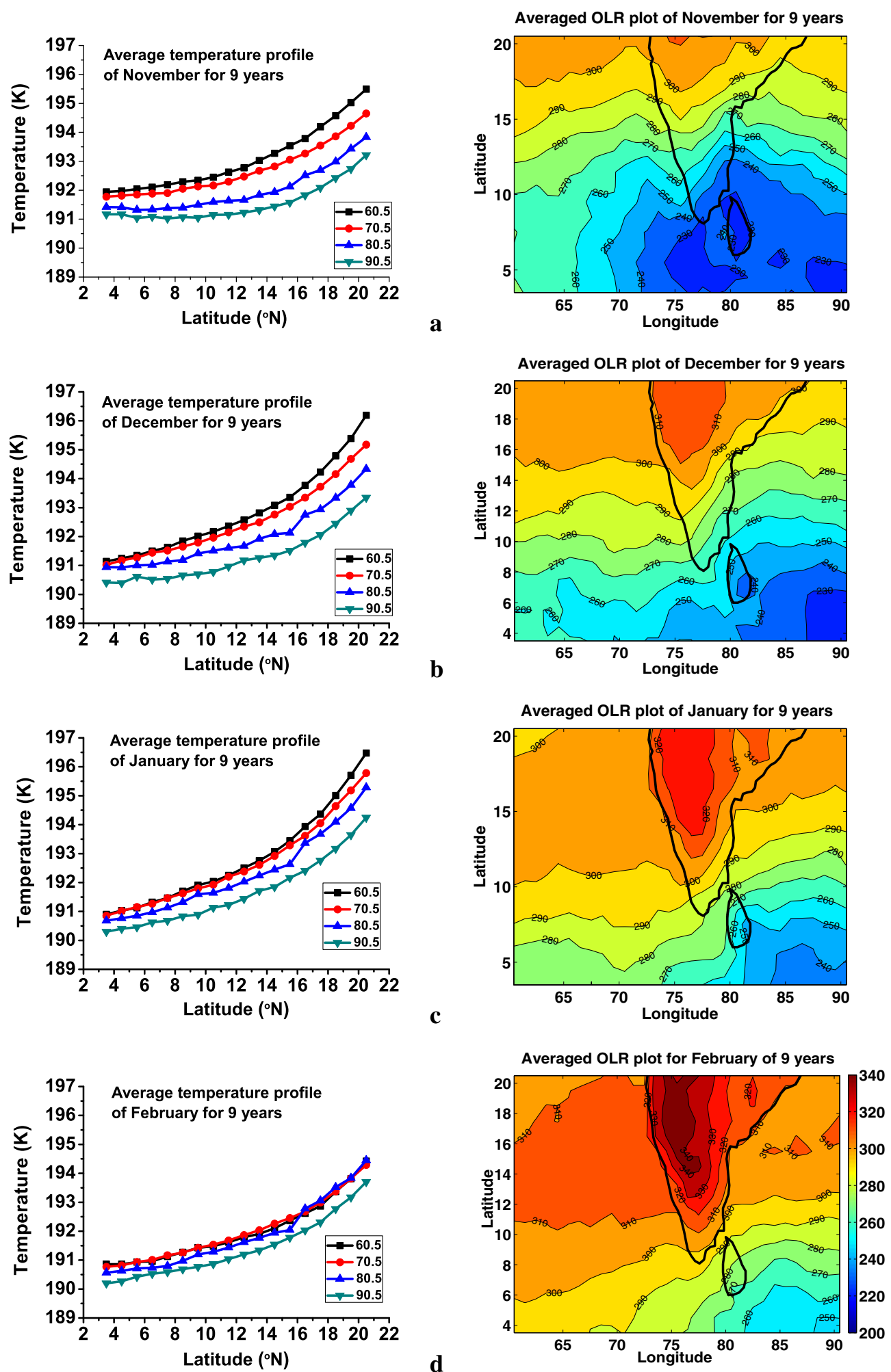

Figure 3. Left panel shows 9 years averaged (from 2003 to 2011) temperature for the winter months (November, December, January and February) and right panel shows 9 years averaged (from 2003 to 2011$)$ OLR over the Indian region $\left(3.5^{\circ}-20.5^{\circ} \mathrm{N}\right.$, $\left.60^{\circ}-90^{\circ} \mathrm{E}\right)$.

Figure 1(a, b, c) (left panels) (for MAM) show the consistent rise in temperature $(\sim 2-3 \mathrm{~K})$ on moving from $3.5^{\circ}$ to $20.5^{\circ} \mathrm{N}$ indicating the exis- tence of latitudinal or meridional temperature gradient decreasing from $\sim 0.18 \mathrm{~K} / \mathrm{deg}$ at $60^{\circ} \mathrm{E}$ to $\sim 0.14 \mathrm{~K} / \mathrm{deg}$ at $90^{\circ} \mathrm{E}$ longitudinally. There has 
been some mention of tropopause temperature variation latitudinally (Kishore et al. 2006; Johny et al. 2009) using satellite data, but their studies did not include any detailed quantitative analysis for this region. The change in temperature may occur due to the presence and northward movement of convective clouds. To explore the effect of convection on temperature, OLR data (taken as a proxy of convection) is analysed as shown in the right panels of figure 1 . One can notice low OLR $\left(\sim 220-240 \mathrm{~W} / \mathrm{m}^{2}\right)$ area (indicated by blue patch) in figure 1, for summer months. This low OLR area further deepens, and becomes prominent in the range of $4^{\circ}-8^{\circ} \mathrm{N}$ covering $\mathrm{AS}$ and $\mathrm{BOB}$ regions, as we move from March to May. This feature of low OLR at the southern tip of Indian peninsula denotes the onset of Indian monsoon, which progressively moves northwards as shown in figure 2 . In this region $\left(4^{\circ}-8^{\circ} \mathrm{N}\right)$, decrease in temperature, is associated with low OLR (enhancement in convection activity) as seen in right panels of figure 1 . The rise in temperature (at latitudes $>10^{\circ} \mathrm{N}$ ) is noted over all the longitudes, i.e., at $60^{\circ}, 70^{\circ}, 80^{\circ}$ and $90^{\circ} \mathrm{E}$. However, the values of temperature are found to be higher over $60^{\circ}$ and $70^{\circ} \mathrm{E}$ (centered $\sim 15^{\circ}-20^{\circ} \mathrm{N}$ ) than for $80^{\circ}$ and $90^{\circ} \mathrm{E}, \sim 1-2 \mathrm{~K}$, which is elaborated later in section 3.2.

In May, at $80^{\circ} \mathrm{E}$ for latitudes $9^{\circ} \mathrm{N}$ to $15^{\circ} \mathrm{N}$, there is a notable feature in variation of temperature. The temperature for these latitudes rises abruptly by $\sim 0.5 \mathrm{~K}$ suggesting that this change is caused by land-sea contrast. This is a consistent feature observed every year during 2003-2011 (not shown). At $90^{\circ} \mathrm{E}$, around BOB, for these latitudes, the temperature is lowest latitudinally in comparison to $60^{\circ}, 70^{\circ}$ and $80^{\circ} \mathrm{E}$. This low temperature $(<190 \mathrm{~K})$ over $\mathrm{BOB}$ is a direct evidence of influence of deep convection over temperature in this region (confirmed by figure 1c). Jain et al. (2011) have discussed that such a low temperature contributes to the troposphere to stratosphere exchange of airmass and can be effective over BOB region even in early period of monsoon season. Our fine-scale observations also support that low temperature $(<190 \mathrm{~K})$ is commonly observed in this area.

To further examine the effect of convection and to describe the detailed feature of monsoonal effect on temperature, we have analysed temperature and OLR data for JJAS as well. The general features and association of temperature and OLR are shown in figure 2. It is observed during JJAS, temperature decreases latitudinally (from $3.5^{\circ}$ to $20.5^{\circ} \mathrm{N}$ ), which is in contrast to the rising trend observed during MAM. The temperature decreases latitudinally for all the four consecutive months (JJAS). This result is almost similar to the analysis done by $\mathrm{Li}$ and Yanai (1996); there is a reversal of meridional upper tropospheric temperature gradient during the active monsoon period, which is responsible for the change in nature of temperature variation. The temperature decreases by $\sim 2.0-2.5 \mathrm{~K}$ as we move from $3.5^{\circ}$ to $20^{\circ} \mathrm{N}$. The decrease in temperature is most probably caused by the northward movement of the monsoon system. One can see the low OLR $\left(\sim 220-240 \mathrm{~W} / \mathrm{m}^{2}\right)$, which was around AS $\left(4^{\circ}-8^{\circ} \mathrm{N}, 70^{\circ}-75^{\circ} \mathrm{E}\right)$ to $\mathrm{BOB}\left(4^{\circ}-8^{\circ} \mathrm{N}, 90^{\circ} \mathrm{E}\right)$ during May shown in figure 1(c), had shifted to $10.5^{\circ}-$ $13.5^{\circ} \mathrm{N}$ during June as seen in figure 2(a). It further extends over the region of $15^{\circ}-20^{\circ} \mathrm{N}$ latitudes during July, August and September (figure 2b, c, d). This northward movement of low OLR (proxy of convection) causes the decrease in temperature as seen in figure 2. Keeping in view the abovementioned results, it appears that there is a close association between occurrence of low temperature and low OLR in the same regions.

The cause for decrease in temperature (collocated with the regions of low OLR) is believed to be partly because of radiative cooling due to the presence of deep convective clouds and partly because of adiabatic expansion of air-mass in the upper troposphere as the vertical wind gets enhanced during the process of vertical growth in convective systems (Dhaka et al. 2001, 2002, 2003, 2006, 2010).

The latitudinal temperature gradient for JJAS increases from $\sim 0.10$ to $\sim 0.14 \mathrm{~K} / \mathrm{deg}$ as we move from $60^{\circ}$ to $90^{\circ} \mathrm{E}$. This can be attributed to the decrease in temperature, for the latitudes $15^{\circ}-20^{\circ} \mathrm{N}$ over $80^{\circ}-90^{\circ} \mathrm{E}$ longitudes, caused by low OLR in the same region. Thus, northward movement of Indian summer monsoon system is responsible for maintaining the northward temperature gradient.

In a recent study, Jain et al. (2010, 2011) have shown that OLR and temperature in the tropopause region are highly correlated. They have used both ARMEX and BOBMEX campaign data along with satellite (CHAMP, COSMIC and KALPANA) observations to show the strong association of OLR and low tropopause temperature in a given region. However, their study was focussed at a particular location and there was no information about the latitudinal variation in that region. As mentioned earlier, Bhat et al. (2001, 2002) had also noted a decrease in temperature of $\sim 2 \mathrm{~K}$ near the tropopause height during the active phase of convection in comparison to weak phase over AS and BOB. Their study was based on the ship observations at some specific locations over $\mathrm{AS}$ and BOB. However, they did not present the fine-scale regional information as we are presenting in this paper using AIRS data.

We further extended the investigation to winter as well, to analyse the overall seasonal behaviour of low OLR and temperature at $100 \mathrm{hPa}$. Winter temperature and OLR data are shown in figure 3 . We observe that there also exists a 
temperature variation (increase in temperature) similar to summer as we move latitudinally (from $3.5^{\circ}$ to $20.5^{\circ} \mathrm{N}$ ); however, the maximum change noted in temperature is of the order of $\sim 4-5 \mathrm{~K}$ (left panels). The latitudinal temperature gradient is found to decrease from $\sim 0.25 \mathrm{~K} / \mathrm{deg}$ at $60^{\circ} \mathrm{E}$ to $\sim 0.18 \mathrm{~K} / \mathrm{deg}$ at $90^{\circ} \mathrm{E}$. It is important to note that the temperature gradient for winter months is larger by a factor of $\sim 1.5$ as compared to summer months suggesting that temperature variation in winter is more than in summer. Also, it is to be noted that the latitudinal variation in temperature $\left(\sim 12.5^{\circ}-20.5^{\circ} \mathrm{N}\right)$, among different longitudes, is more for the months of November and December as compared to January and February. To further examine, we also plotted 9 years of averaged OLR data for the winter months, shown in the right panels of figure 3. Figure 3(a) shows that low OLR $\left(\sim 220-240 \mathrm{~W} / \mathrm{m}^{2}\right)$ is located in the region $4.5^{\circ}-$ $8.5^{\circ} \mathrm{N}$ and $80^{\circ}-90^{\circ} \mathrm{E}$ and it shifts towards equator and enters into southern hemisphere with the passage of time (from December to February). The occurrence of low OLR at lower latitudes $\left(4.5^{\circ}-\right.$ $8.5^{\circ} \mathrm{N}$ ) during November and December is responsible for larger variation in temperature $\left(12.5^{\circ}-\right.$ $20.5^{\circ} \mathrm{N}$, among different longitudes), as compared to January and February which are observed to be dry.

It is also seen that the latitudinal difference in temperature variation for the winter months is higher than summer and summer monsoon months. Analysis suggests that variation in temperature is because of the presence of convection (i.e., low OLR) in particular months that defines the thermal structure in a particular latitudinal range.

\subsection{Longitudinal variation of average temperature and OLR during 2003-2011}

For all seasons, it is noticed that temperature, at $100 \mathrm{hPa}$, is higher on AS side compared to BOB by $\sim 1-2 \mathrm{~K}$. The low temperature observed around $80^{\circ}$ and $90^{\circ} \mathrm{E}(\mathrm{BOB})$ in most of the months, appears to be associated with deep convection as seen in the right panels of the figures 1,2 and 3. It is also noted that low OLR is located near $90^{\circ} \mathrm{E}$ longitude, which is also the region of lowest temperature. It is also observed during summer, summer monsoon and winter months, the variation in temperature is observed to be gradual over $60^{\circ}, 70^{\circ}$ and $90^{\circ} \mathrm{E}$ longitudes. However for $80^{\circ} \mathrm{E}$, the temperature shows a sudden rise and fall by $\sim 0.5-0.6 \mathrm{~K}$ around $8^{\circ}-$ $10^{\circ} \mathrm{N}$ and $15^{\circ}-17^{\circ} \mathrm{N}$, respectively. Such changes are attributed to land-sea contrast, which could be only be noted at such fine scale using AIRS data.

Correlation coefficient $\left(R_{\mathrm{xy}}\right)$ is also computed between OLR and temperature (shown in table 1)
Table 1. Value of correlation coefficient $\left(R_{\mathrm{xy}}\right)$ between $O L R$ and temperature for individual months at different longitudes. Computed values are at 95\% confidence level. Bold values indicate monsoon months, which change sign from negative to positive, showing the association of low OLR with low temperature. The italicized values are non-significant at 95\% confidence level.

\begin{tabular}{lrrrr}
\hline \multirow{4}{*}{ Months } & \multicolumn{4}{c}{ Longitudes } \\
\cline { 2 - 5 } March & $60^{\circ} \mathrm{E}$ & $70^{\circ} \mathrm{E}$ & $80^{\circ} \mathrm{E}$ & $90^{\circ} \mathrm{E}$ \\
April & 0.57 & 0.82 & 0.92 & 0.76 \\
May & 0.66 & 0.91 & 0.96 & 0.87 \\
June & 0.92 & 0.93 & 0.85 & 0.72 \\
July & $\mathbf{- 0 . 9 3}$ & $\mathbf{- 0 . 5 1}$ & 0.31 & $\mathbf{0 . 9 5}$ \\
August & $\mathbf{- 0 . 7 3}$ & $\mathbf{- 0 . 5 7}$ & $\mathbf{0 . 7 4}$ & $\mathbf{0 . 7 3}$ \\
September & $\mathbf{- 0 . 7 1}$ & $\mathbf{- 0 . 6 9}$ & $\mathbf{0 . 7 3}$ & $\mathbf{0 . 9 4}$ \\
November & $\mathbf{- 0 . 9 5}$ & $\mathbf{- 0 . 8 2}$ & $\mathbf{0 . 5 6}$ & $\mathbf{0 . 4 3}$ \\
December & 0.94 & 0.97 & 0.95 & 0.79 \\
January & 0.85 & 0.89 & 0.94 & 0.87 \\
February & 0.55 & 0.79 & 0.89 & 0.88 \\
\hline
\end{tabular}

at each longitude $\left(60^{\circ}, 70^{\circ}, 80^{\circ}\right.$ and $\left.90^{\circ} \mathrm{E}\right)$ latitudinally $\left(3.5^{\circ}-20.5^{\circ} \mathrm{N}\right)$. It is computed for each month to examine the association of OLR and temperature during different seasons. $R_{\mathrm{xy}}$ is found to vary between 0.70 and 0.92 during winters (NDJF) and summers (MAM), i.e., $R_{\mathrm{xy}}$ does not change at different longitudes. However, for monsoon months (JJAS), $R_{\mathrm{xy}}$ is negative (between -0.70 and -0.93 ) over $60^{\circ}-70^{\circ} \mathrm{E}$ longitudes and it becomes positive (from 0.70 to 0.92 ) (shown as bold) over $80^{\circ}-90^{\circ} \mathrm{E}$ longitudes indicating convective activity to be the key factor in controlling the temperature at $100 \mathrm{hPa}$. All the values are significant at 95\% confidence level and non-significant values are shown in italics. In a recent work, Dhaka et al. (2010) have shown the role of convection activity on temperature using about 3 decades of data over Kolkata $\left(22.3^{\circ} \mathrm{N}, 88.2^{\circ} \mathrm{E}\right)$ station. Both seasonal and long-term effects of convection have been identified in their study. However, in this study, satellite observation enabled us to examine such features at a fine spatial and temporal scale in the range of $3.5^{\circ}-20.5^{\circ} \mathrm{N}$ covering the region from $\mathrm{AS}$ to BOB.

The current observations have enabled us to present the gradual and systematic change in temperature and low OLR latitudinally in different months (using 9 years of data) and for different seasons (summer, summer monsoon and winter) as well. We can also see the contrast behaviour at the location of land and sea which was not reported earlier by any of the recent studies due to the unavailability of data at a fine spatial and temporal scale. 


\section{Summary and concluding remarks}

This study is mainly centered over the Indian region $\left(3.5-20.5^{\circ} \mathrm{N}, 60-90^{\circ} \mathrm{E}\right)$ to investigate the changes in temperature during summer, summer monsoon and winter months at $100 \mathrm{hPa}$. Present study shows observations on both land and sea simultaneously at a fine spatial and temporal resolution. We have taken monthly averaged temperature data and analysed its meridional variation at different longitudes $\left(60^{\circ}-90^{\circ} \mathrm{E}\right.$ at an interval of $10^{\circ}$ longitudes). Following are the important conclusions:

(1) For the summer months, temperature increases latitudinally by $\sim 2-3 \mathrm{~K}$. This latitudinal increase in temperature can be accounted for the onset of monsoon at low latitudes $\left(3.5^{\circ} \mathrm{N}\right)$ as compared to $20.5^{\circ} \mathrm{N}$ latitudes (shown in right panels in figure 1). Latitudinal temperature gradient is found to decrease from $\sim 0.18$ to $0.14 \mathrm{~K} / \mathrm{deg}$ over the longitudes $60^{\circ}$ to $90^{\circ} \mathrm{E}$, respectively. For the summer monsoon (JJAS), the temperature decreases latitudinally $(\sim 2.0-$ $2.5 \mathrm{~K}$ ), which is in contrast to the rising trend observed during MAM. This decrease in temperature is due to northward movement of low OLR as shown in the right panels of figure 2, suggesting that deep convection is a cause of such change. The latitudinal temperature gradient (for JJAS) increases from $\sim 0.10 \mathrm{~K} / \mathrm{deg}$. (at $60^{\circ} \mathrm{E}$ ) to $\sim 0.14 \mathrm{~K} / \mathrm{deg}$ (at $90^{\circ} \mathrm{E}$ ) longitudinally. It is also noted for summer (during May) and summer monsoon months, at $80^{\circ} \mathrm{E}$, the temperature shows a sudden rise and fall by $\sim 0.5-0.6 \mathrm{~K}$ around $8^{\circ}-10^{\circ} \mathrm{N}$ and $15^{\circ}-$ $17^{\circ} \mathrm{N}$, respectively, showing land-sea contrast characteristics.

(2) For the winter months, the temperature increases by $\sim 4-5 \mathrm{~K}$ from $3.5^{\circ}$ to $20.5^{\circ} \mathrm{N}$. The latitudinal variation in temperature $\left(\sim 12.5^{\circ}\right.$ $20.5^{\circ} \mathrm{N}$ ), among different longitudes, is more for the months of November and December as compared to January and February. Latitudinal temperature gradient for winter months $(\sim 0.25-0.18 \mathrm{~K} / \mathrm{deg})$ is larger by a factor of 1.5 than the summer months $(\sim 0.18-0.14 \mathrm{~K} / \mathrm{deg})$.

(3) For all the months, it is noted that the temperature decreases while moving from $60^{\circ}$ to $90^{\circ} \mathrm{E}$. At $90^{\circ} \mathrm{E}$, i.e., $\mathrm{BOB}$, the temperature is lowest in comparison to $60^{\circ}, 70^{\circ}$ and $80^{\circ} \mathrm{E}$. Such a decrease in temperature is mostly due to appearance of deep convection in this region, which is confirmed by the low OLR (right panels of figure 2).

(4) Correlation coefficient $\left(R_{\mathrm{xy}}\right)$ between OLR and temperature is computed latitudinally for all the months (shown in table 1). For monsoon months, $R_{\mathrm{xy}}$ is negative ranging from -0.70 to -0.93 over $60^{\circ}-70^{\circ} \mathrm{E}$ longitudes and it becomes positive $\sim 0.70$ to 0.92 over $80^{\circ}-90^{\circ} \mathrm{E}$ longitudes indicating convective activity to be the key factor in controlling the temperature at $100 \mathrm{hPa}$ centered over BOB. Positive $R_{\mathrm{xy}}$ denotes that there is a long stretch of low OLR and low temperature northward; however, negative $R_{\mathrm{xy}}$ shows that OLR may be centered over, say $10^{\circ} \mathrm{N}$, and not stretched on either side.

(5) We have examined the year-to-year variation of temperature over 2003-2011 for the summer (MAM), summer monsoon (JJAS) and winter months (NDJF) over Indian region. We notice that nature of the temperature variation observed over different years individually is similar, as studied for the averaged values of temperature over the 9 years (shown in figure A2). An interesting feature noticed while studying the year-to-year variation is that the temperature values are maximum for the year 2009. This is similar to the finding, which is reported by WMO (http://www.weather. gov.hk/wxinfo/pastwx/ywx2009.html) that the year 2009 was a warm year in comparison to the years 2003-2011. This suggests that signature of warming is not only confined to the lower heights, rather they appear even at the $100 \mathrm{hPa}$ level as well.

(6) We have also shown the variation of height of cold point tropopause (H-CPT) in different seasons (see figure A3). Averaged H-CPT (available with AIRX3STM) is plotted during summer months (MAM), monsoon months (JJAS) and winter months (NDJF) using 9 years (2003-2011) of data over the Indian region. The results suggest that the height $(\mathrm{H}-\mathrm{CPT})$ is found to be maximum $(16.90 \mathrm{~km})$ for the winter month (February), which decreases to $16.38 \mathrm{~km}$ during the monsoon period (August). Its finescale details will be examined in our ongoing work.

\section{Acknowledgements}

Satellite data are obtained from http://airs.jpl. nasa.gov/. Present work is supported by ISRO/ DOS, Government of India, through a research project under CAWSES-India Program. The authors thank Dr Venkat M Ratnam, Dr Thomas Hearty, Dr S Wong, Prof. Joanne Haigh and Dr C K Liang for their helpful suggestions regarding the retrievals of temperature profiles from AIRS during the progress of this work. The authors also thank the reviewers for their helpful comments and suggestions. 


\section{Annexure}
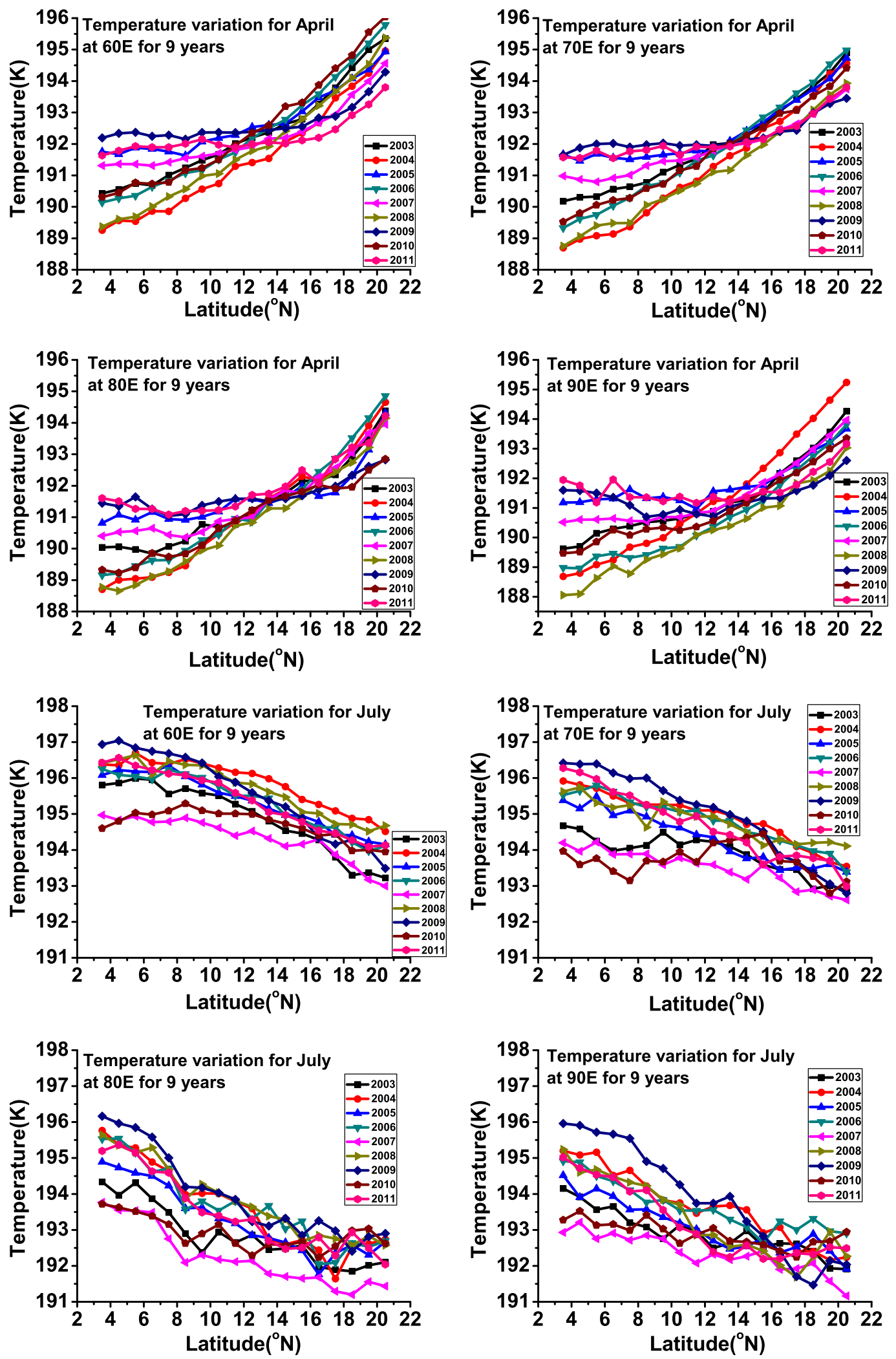

Figure A1. Latitudinal variability of temperature during April and July for all the years (2003-2011) showing contrasting behaviour. 

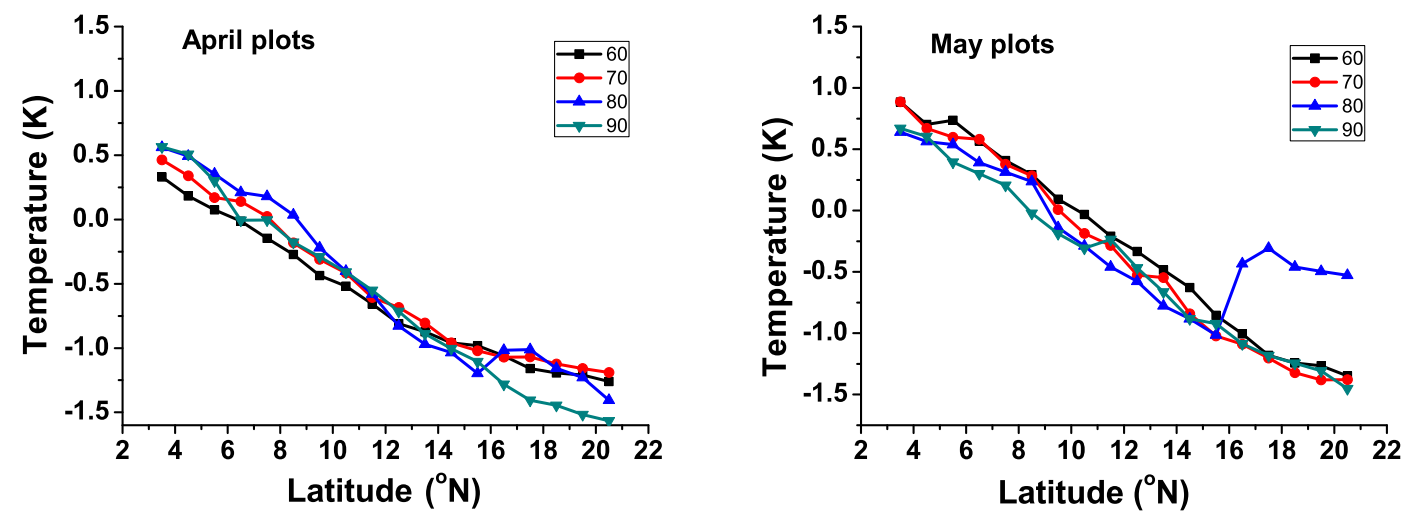

April \& May (summer months)
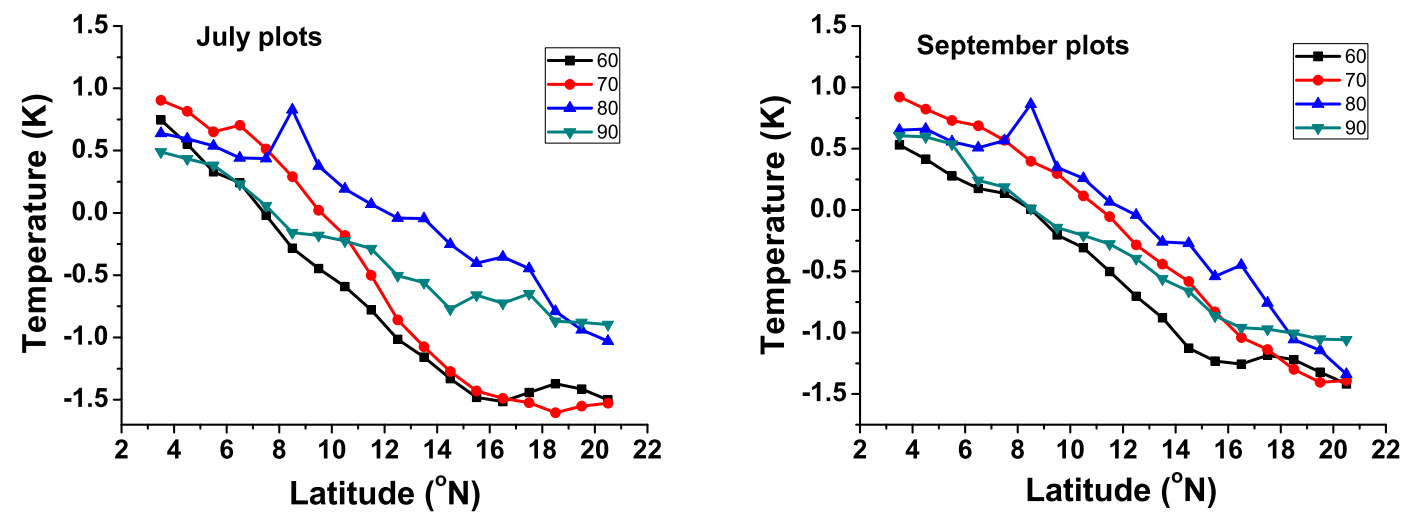

July \& September (monsoon months)
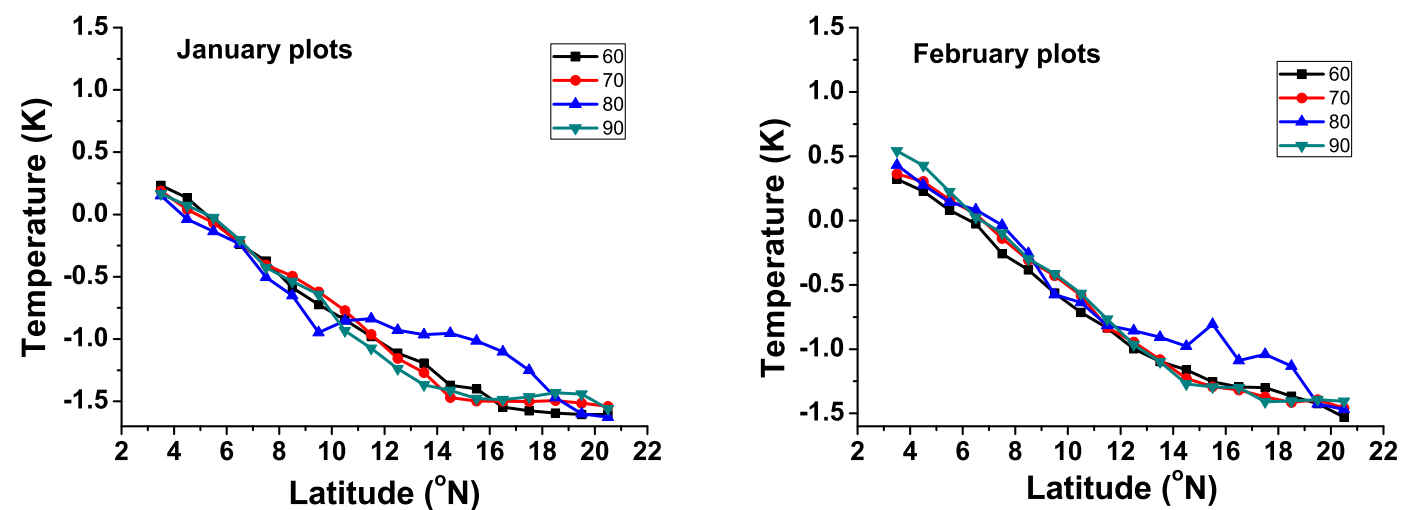

January \& February (winter months)

Figure A2. Plots showing bias between MW and combined IR/MW retrievals with latitude for different seasons. 


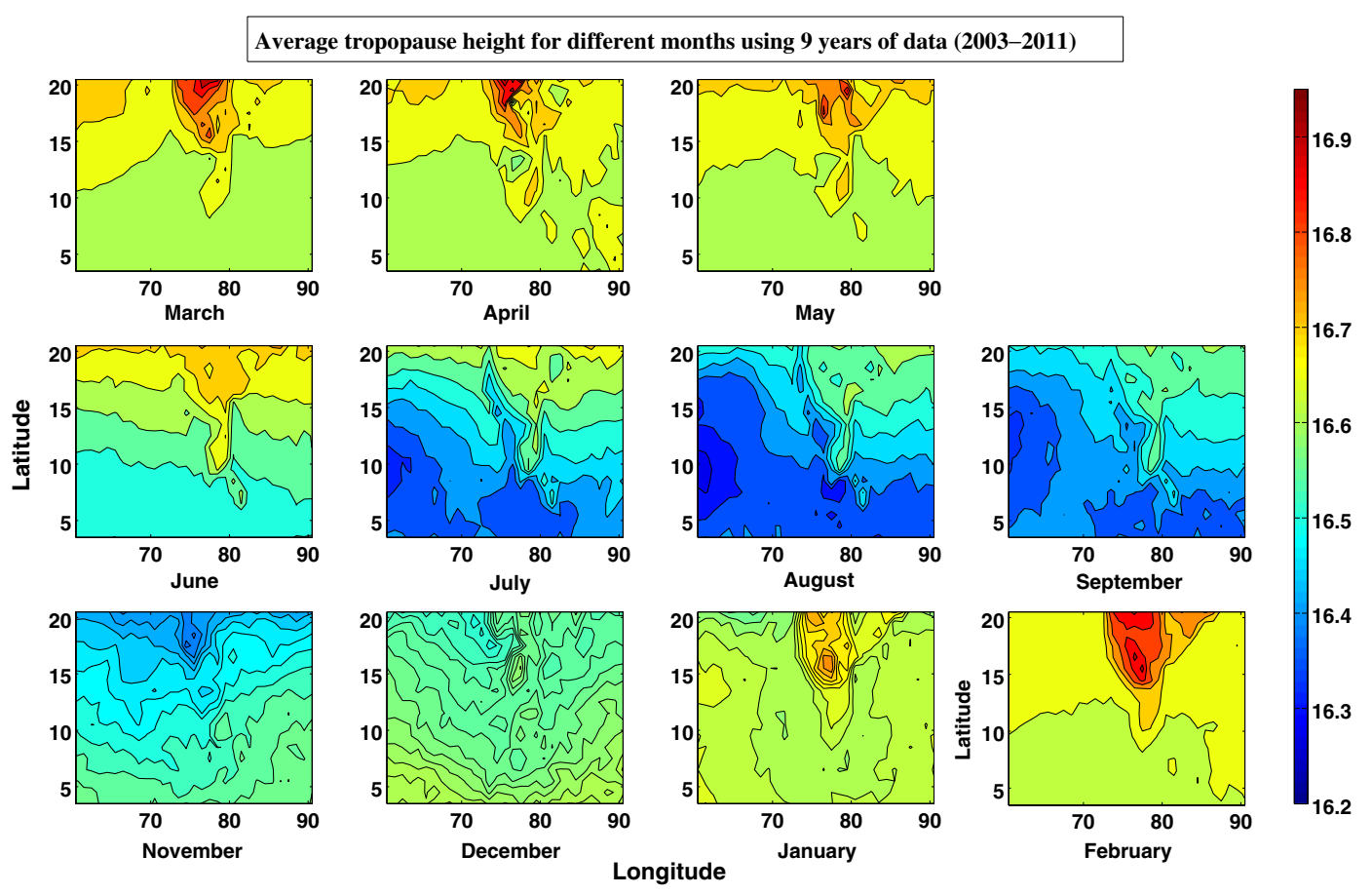

Figure A3. Tropopause height (H-CPT) for three seasons using 9 years of data. Top panel denotes summer months (MAM), middle panel, the monsoon months (JJAS) and lower panel, the winter months (NDJF).

\section{References}

Aumann H H, Chahine M T, Gautier C, Goldberg M D, Kalnay E, McMillin L M, Revercomb H, Rosenkranz P W, Smith W L and Staelin D H 2003 AIRS/AMSU/HSB on the aqua mission: Design, science objectives, data products, and processing systems; IEEE Trans. Geosci. Rem. Sens. 41(2) 253-264, doi: 10.1109/tgrs.2002.808356.

Baray J L, Ancellet G, Taupin G, Bessafi M, Baldy S and Keckhut P 1998 Subtropical tropopause break as a possible stratospheric source of ozone in the tropical troposphere; J. Atmos. Sol.-Terr. Phys. 60 27-36.

Bhat G S et al. 2001 BOBMEX: The Bay-of-Bengal Monsoon Experiments; Bull. Am. Meteorol. Soc. 82 2217-2243.

Bhat G S, Chakarbarty A, Nanjundiah R S and Srinivasan J 2002 Vertical structure of the atmosphere during active and weak phases of convection over the north Bay of Bengal: Observation and model results; Curr. Sci. 83(3) 296-302.

Chahine M T et al. 2006 AIRS: Improving weather forecasting and providing new data on greenhouse gases; Bull. Am. Meteorol. Soc. 87 911-926.

Dhaka S K, Devrajan P K, Shibagaki Y, Choudhary R K and Fukao S 2001 Indian MST radar observations of gravity wave activities associated with tropical convection; J. Atmos. Sol.-Terr. Phys. 63 1631-1642.

Dhaka S K, Choudhary R K, Malik S, Shibagaki Y, Yamanaka M D and Fukao S 2002 Observable signatures of convectively generated wave field over tropics using Indian MST radar at Gadanki $\left(13.47^{\circ} \mathrm{N}, 79.18^{\circ} \mathrm{E}\right)$; Geophys. Res. Lett. 29(18) 1872.

Dhaka S K, Takahashi M, Kawatani Y, Shibagaki Y and Fukao S 2003 Observations of deep convective updrafts in tropical convection and their role in the generation of gravity waves; J. Meteorol. Soc. Japan 81(5) 1185-1199.

Dhaka S K, Yamamoto M K, Shibagaki Y, Hashiguchi H, Fukao S and Chun H-Y 2006 Equatorial atmosphere radar observations of short vertical wavelength gravity waves in the upper troposphere and lower stratosphere region induced by localized convection; Geophys. Res. Lett. 33 L19805, doi: 10.1029/2006GL027026.

Dhaka S K, Sapra R, Panwar V, Goel A, Bhatnagar R, Kaur M, Mandal T K, Jain A R and Chun H Y 2010 Influence of large-scale variations in convective available potential energy (CAPE) and solar cycle over temperature in the tropopause region at Delhi $\left(28.3^{\circ} \mathrm{N}\right.$, $\left.77.1^{\circ} \mathrm{E}\right)$, Kolkata $\left(22.3^{\circ} \mathrm{N}, 88.2^{\circ} \mathrm{E}\right)$, Cochin $\left(10^{\circ} \mathrm{N}, 77^{\circ} \mathrm{E}\right)$ and Trivandrum $\left(8.5^{\circ} \mathrm{N}, 77.0^{\circ} \mathrm{E}\right)$ using radiosonde during 1980-2005; Earth Planet. Space 62 319-331.

Divakarla M G, Barnet C D, Goldberg M D, McMillin L M, Maddy E, Wolf W, Zhou L and Liu X 2006 Validation of atmospheric infrared sounder temperature and water vapor retrievals with matched radiosonde measurements and forecasts; J. Geophys. Res. 111 D09S15, doi: 10.1029/2005JD006116.

Fetzer E J 2006 Preface to special section: Validation of atmospheric infrared sounder observations; J. Geophys. Res. 111 D09S01, doi: 10.1029/2005JD007020.

Gao W, Zhao F and Gai C 2006 Validation of AIRS retrieval temperature and moisture products and their application in numerical models; Acta Metorol. Sin. 64 271-280.

Highwood E J and Hoskins B J 1998 The tropical tropopause; Quart. J. Roy. Meteorol. Soc. 124 1579-1604, doi: 10.1002/qj.49712454911.

Holton J R, Haynes P H, McIntyre M E, Douglass A R, Rood R B and Pfister L 1995 Stratosphere-troposphere exchange; Rev. Geophys. 33 403-439.

Jain A R, Panwar V, Mandal T K, Rao V R, Goel A, Gautam R, Das S S and Dhaka S K 2010 Mesoscale convection system and occurrence of extreme low tropopause observations over Asian summer monsoon region; Ann. Geophys. 28 927-940.

Jain A R, Panwar V, Johny C J, Mandal T K, Rao V R, Gautam R and Dhaka S K 2011 Occurrence of extreme low cold point tropopause temperature during summer 
monsoon season: ARMEX campaign and CHAMP and COSMIC satellite observations; J. Geophys. Res. 116 D03102, doi: 10.1029/2010JD014340.

Jiang J H, Wang B, Goya K, Hocke K, Eckermann S D, Ma J, Wu D L and Read W G 2004 Geographical distribution and interseasonal variability of tropical deep convection: UARS MLS observations and analyses; J. Geophys. Res. 109 D03111, doi: 10.1029/2003JD003756.

Johny C J, Sarkar S K and Punyasesudu D 2009 Atmospheric phenomena deduced from radiosonde and GPS occultation measurements for various application related studies; J. Earth Syst. Sci. 118(1) 49-59.

Kishore P, Namboothiri S P, Igarashi K, Jonathan H Jiang, Chi O Ao and Larry J Roamns 2006 Climatological characteristics of the tropical tropopause parameters derived from GPS/CHAMP and GPS/SAC-C satellite measurements; J. Geophys. Res. 111 D20110, doi: 10.1029/2005JD006827.

Lambrigtsen B H 2003 Calibration of the AIRS microwave instruments; IEEE Trans. Geosci. Rem. Sens. 41(2) 369378, doi: $10.1109 /$ tgrs.2002.808247.

Li C and Yanai M 1996 The onset and interannual variability of the Asian summer monsoon in relation to land--sea thermal contrast; J. Clim. 9 358-375.

Liang C K, Eldering A, Gettelman A, Tian B, Wong S, Fetzer E J and Liou K N 2011 Record of tropical interannual variability of temperature and water vapor from a combined AIRS-MLS data set; J. Geophys. Res. 116 D06103, doi: 10.1029/2010JD014841.

Newell R E and Gould S S 1981 A stratospheric fountain; J. Atmos. Sci. 38 2789-2796, doi: 10.1175/1520-0469.

Olsen E T, Susskind J, Blaisdell J and Rosenkranz P 2007a AIRS/AMSU/HSB version 5 level 2 quality control and error estimation; JPL/NASA, California Institute of Technology, Pasadena, USA, 15p.

Olsen E T, Granger S, Manning E and Blaisdell J 2007b AIRS/AMSU/HSB version 5 level 3 quick start, JPL/ NASA, California Institute of Technology, Pasadena, USA, 25p.

Pan L L, Randel W J, Gary B L, Mahoney M J and Hinsta E J 2004 Definitions and sharpness of the extratopical tropopause: A trace gas perspective; J. Geophys. Res. 109 D23103, doi: 10.1029/2004JD004982.

Randel W J, Wu F and Gaffen D J 2000 Interannual variability of the tropical tropopause derived from radiosonde data and NCEP reanalysis; J. Geophys. Res. 105(D12) $15,509-15,523$.

Ratnam M V, Tsuda T, Shiotani M and Fujiwara M 2005 New characteristics of tropical tropopause revealed by CHAMP/GPS measurements; Sci. Online Lett. Atmos. 1 185-188, doi: 10.2151/sola2005-048.

Rosenlof K H et al. 2001 Stratospheric water vapour increases over the past half century; Geophys. Res. Lett. 28 1195-1199.

Sherwood S C and Dessler A E 2001 A model for transport across the tropical tropopause; J. Atmos. Sci. 58 765779, doi: 10.1175/1520-0469.

Sorensen J H and Nielsen N W 2001 Intrusion of stratospheric ozone to the free troposphere through tropopause folds - A case study; Phys. Chem. Earth (B) 26 801806.

Susskind J, Barnet C and Blaisdell J 2003 Retrieval of atmospheric and surface parameters from AIRS/AMSU/HSB Data in the presence of clouds; IEEE Trans. Geosci. Rem. Sens. 41(2) 390-409.

Susskind J, Barnet C, Blaisdell J, Iredell L, Keita F, Kouvaris L, Molnar G and Chahine M 2006 Accuracy of geophysical parameters derived from Atmospheric Infrared Sounder/Advanced Microwave Sounding Unit as a function of fractional cloud cover; J. Geophys. Res. 111(D9) D09S17, doi: 10.1029/2005jd006272.

Tobin D C, Revercomb H E, Knuteson R O, Lesht B M, Strow L L, Hannon S E, Feltz W F, Moy L A, Fetzer E J and Cress T S 2006 Atmospheric radiation measurement site atmospheric state best estimates for AIRS temperature and water vapor retrieval validation; J. Geophys. Res. 111 D09S14, doi:10.1029/2005JD006103.

Yunck T P, Fetzer E J, Mannucci A M, Ao C O, Irion F W, Wilson B D and Manipon G J M 2009 Use of radio occultation to evaluate atmospheric temperature data from spaceborne infrared sensors; Terr. Atmos. Ocean. Sci. 20 71-85, doi:10.3319/TAO.2007.12.08.01(F3C). 